\title{
Article/Artigo
}

\section{Predictors of adherence to influenza vaccination for healthcare workers from a teaching hospital: a study in the prepandemic era}

\author{
Preditores de adesão à vacinação contra influenza em profissionais de um hospital de ensino: \\ um estudo na era pré-pandêmica
}

\author{
Ricardo de Souza Cavalcante ${ }^{1,2}$, Aline Maia Zambonatto Jorge ${ }^{1}$ and Carlos Magno Castelo Branco Fortaleza ${ }^{1,2,3}$
}

\begin{abstract}
Introduction: Even before the 2009 pandemics, influenza in healthcare workers (HCW) was a known threat to patient safety, while Influenza vaccine coverage in the same group was generally low. Identification of predictors for $\mathrm{HCW}$ adherence to Influenza vaccination has challenged infection control committees. Methods: Our group conducted a cross-sectional survey in December 2007, interviewing 125 HCWs from a teaching hospital to identify adherence predictors for Influenza vaccination. The outcomes of interest were: A - adherence to the 2007 vaccination campaign; B - adherence to at least three yearly campaigns in the past five years. Demographic and professional data were assessed through univariate and multivariate analysis. Results: Of the HCWs interviewed, $43.2 \%$ were vaccinated against Influenza in 2007. However, only $34.3 \%$ of HCWs working in healthcare for more than five years had adhered to at least three of the last five vaccination campaigns. Multivariate analysis showed that working in a pediatric unit $(\mathrm{OR}=7.35,95 \% \mathrm{CI}=1.90-28.44, \mathrm{p}=0.004)$ and number of years in the job $(\mathrm{OR}=1.32,95 \% \mathrm{CI}=1.00-1.74, \mathrm{p}=0.049)$ were significant predictors of adherence to the 2007 campaign. Physicians returned the worst outcome performances in $\mathrm{A}(\mathrm{OR}=0.40$, $95 \% \mathrm{CI}=0.16-0.97, \mathrm{p}=0.04)$ and $\mathrm{B}(\mathrm{OR}=0.17,95 \% \mathrm{CI}=0.05-0.60, \mathrm{p}=0.006)$. Conclusions: Strategies to improve adherence to Influenza vaccination should focus on physicians and newly-recruited HCWs. New studies are required to assess the impact of the recent Influenza A pandemics on $\mathrm{HCW}$-directed immunization policies.
\end{abstract}

Key-words: Influenza. Vaccination. Healthcare workers.

\section{RESUMO}

Introdução: Mesmo antes da pandemia de 2009, o acometimento de profissionais da área da saúde (PAS) pela influenza já era uma ameaça conhecida para pacientes internados. A cobertura vacinal desse grupo era geralmente baixa. A identificação de preditores de adesão de PAS à vacinação contra influenza é um desafio para Comissões de Controle de Infecção. Métodos: Realizou-se estudo transversal em Dezembro de 2007, entrevistando 125 PAS de um hospital de ensino para identificar preditores de adesão à vacinação contra influenza. Os desfechos de interesse foram: A - adesão à campanha de 2007; B - adesão a pelo menos três campanhas nos últimos cinco anos. Dados demográficos e profissionais foram analisados em modelos univariados e multivariados. Resultados: Dos entrevistados, $43,2 \%$ haviam sido vacinados em 2007. No entanto, apenas 34,3\% daqueles trabalhando há mais de cinco anos aderiram a três ou mais campanhas nesse período. Análise multivariada demonstrou que trabalhar em enfermaria pediátrica $(\mathrm{OR}=7.35,95 \% \mathrm{CI}=1.90-28.44, \mathrm{p}=0,004)$ e o número de anos no emprego $(\mathrm{OR}=1.32,95 \% \mathrm{CI}=1.00-1.74, \mathrm{p}=0.049)$ foram preditores significantes de adesão em 2007. Médicos tiveram má performance nos desfechos $\mathrm{A}(\mathrm{OR}=0,40,95 \% \mathrm{CI}=$ $0.16-0.97, \mathrm{p}=0,04)$ e $\mathrm{B}(\mathrm{OR}=0,17,95 \% \mathrm{CI}=0,05-0,60, \mathrm{p}=0,006)$. Conclusões: Estratégias para aumentar adesão à vacinação contra influenza devem priorizar médicos e PAS admitidos recentemente ao emprego. Novos estudos são necessários para abordar o impacto da recente pandemia de influenza sobre as políticas de vacinação para PAS.

Palavras-chaves: Influenza. Vacinação. Profissionais da Saúde.

1. Bauru State Hospital, Botucatu School of Medicine, São Paulo State University, Bauru, SP, Brazil. 2. Américo Brasiliense State Hospital, Botucatu School of Medicine, São Paulo State University, Américo Brasiliense, SP, Brazil. 3.Department of Tropical Diseases, Botucatu School of Medicine, São Paulo State University, Botucatu, SP, Brazil.

Address to: Dr. Carlos Magno Castelo Branco Fortaleza. Dept ${ }^{\circ}$ Doenças Tropicais e Diagnóstico por Imagem/UNESP. Distrito de Rubião Junior s/n, 18618-979 Botucatu, SP, Brazil.

Phone: 551438116212

e-mail: cmfortaleza@uol.com.br

Received in 22/12/2009

Accepted in 20/08/2010

\section{INTRODUCTION}

The 2009 Influenza A pandemics highlighted an old problem, the role of healthcare workers (HCWs) in nosocomial transmission of influenza ${ }^{1}$. The spread of influenza virus within acute-care hospitals is well documented. Outbreak reports from non-pandemic years provide evidence of both patient-to-patient and staff-to-patient cross-infection. This is worrying, since inpatients usually belong to groups that are vulnerable to severe complications from influenza. Those groups comprise the elderly, infants and patients with chronic diseases or immune suppressed conditions ${ }^{2,3}$.

Staff members play a major role in influenza spread in hospitals. It is estimated that 13 to $20 \%$ of unvaccinated HCWs are infected with influenza virus each winter. Since many of them have mild symptoms, they usually continue working while infectious. They can therefore act as a source of the virus for other HCWs and patients ${ }^{4,5}$.

Influenza vaccine coverage in HCWs is usually low, ranging from 18 to $40 \%^{2-4}$. Poor adherence to vaccination in HCWs has been a matter of intense debate. Misperception of influenza risks and the lack of conveniently available vaccine are usually cited as reasons for this phenomenon ${ }^{6}$.

Knowledge concerning HCW characteristics that are associated with adherence to vaccination is a starting point for implementing strategies aimed at improving influenza vaccine coverage. This was the purpose of the present study.

\section{METHODS}

\section{Setting}

The study was conducted in Bauru State Hospital, a 285-bed general teaching hospital that provides tertiary care for a population of approximately one million inhabitants. The hospital has four intensive care units (ICUs) and several wards that admit medical, surgical and pediatric patients. There is an active Infection Control Committee that is responsible for HCW immunization. The hospital has 828 HCWs, including physicians, nurses and nursing auxiliaries/technicians. 


\section{Study design}

A cross-sectional survey was conducted in December 2007. A random sample of HCWs was selected for interview by one of the researchers. The interview consisted of two sections: the first aimed at identifying adherence predictors for influenza vaccination; the second to assess HCW knowledge on isolation precaution practices for several infectious diseases. This paper presents the results of the first part of the study. However, since knowledge regarding influenza isolation precautions may interfere in the likelihood of being vaccinated, this variable was included in the analysis.

\section{Sample size}

Sample size was calculated using statistical software (Open EPI, (C) Emory University). Vaccination coverage of $40 \%$ with $10 \%$ absolute precision was anticipated. The suggested sample size was 86 HCWs. However, in order to achieve a better representation of all the hospital units, the sample was expanded to 125 individuals.

\section{Study variables}

Data collected during interview included demographics, professional category, number of years since graduation, number of years working in the hospital and simultaneous jobs in other healthcare settings. HCWs were also asked to report the average number of patients they cared for on a weekly basis, including those under isolation precautions. They were also asked to identify the correct isolation precautions indicated for patients with suspected or confirmed influenza. Answers were evaluated according to the Centers for Disease Control and Prevention Guidelines for Isolation Precautions in Hospitals $(1996)^{7}$, which recommend placing patients with influenza-like illnesses under precautions for contact and droplet transmission.

\section{Outcomes of interest}

The study focused on two outcomes: 1) vaccination against in influenza in 2007; 2) vaccination against influenza in at least three campaigns in the last five years. In analysis of the first outcome, data from all $125 \mathrm{HCWs}$ interviewed was included. For the second, only data from HCWs working in the healthcare field for five years or more prior to the interview was analyzed.

\section{Statistical analysis}

The data was submitted to univariate and multivariate analyses using statistics software (SPSS 15.0, (c) SPSS inc). Univariate analysis used the Chi square and Fisher's Exact texts for dichotomous variables and Student T or Mann-Whitney U test for continuous variables. Multivariate analysis consisted of logistic regression models. A conditional stepwise forward approach was used to select variables ${ }^{8}$. P values $<0.1$ and $<0.05$ were required to enter and remain in the models, respectively. A P value of less than 0.05 was also set as the final limit for statistical significance.

\section{Ethical}

This work forms part of a project entitled Attitudes of Healthcare Workers Concerning Infection Control and Professional Protection Measures, which was fully approved by the reference Research in Ethics Committee. Participation by HCWs was voluntary and signed free informed consent was obtained from all study participants.

\section{RESULTS}

\section{Adherence to the 2007 influenza vaccination campaign}

Of the $125 \mathrm{HCW}$ interviewed, 54 (43.2\%) had been vaccinated against influenza in 2007. Analysis of adherence predictors to vaccination in 2007 is presented in Table 1. Multivariate analysis

TABLE 1 - Predictors of $\mathrm{HCW}$ adherence to the 2007 influenza vaccination campaign: univariate and multivariate analysis.

\begin{tabular}{|c|c|c|c|c|c|c|}
\hline \multirow[b]{3}{*}{ Predictors } & \multicolumn{4}{|c|}{ Univariate analysis } & & \\
\hline & \multirow{2}{*}{$\begin{array}{l}\text { vaccinated } \\
\qquad(\mathrm{n}=54)\end{array}$} & \multirow{2}{*}{$\begin{array}{l}\text { not vaccinated } \\
\qquad(\mathrm{n}=71)\end{array}$} & \multirow[b]{2}{*}{ OR $(95 \% \mathrm{CI})$} & \multirow[b]{2}{*}{$\mathrm{P}$} & \multicolumn{2}{|c|}{ Multivariate analysis } \\
\hline & & & & & OR (95\% CI) & $\mathrm{P}$ \\
\hline \multicolumn{7}{|l|}{ Demographic data } \\
\hline male & $12(22.2)$ & $24(33.8)$ & $0.56(0.25-1.26)$ & 0.16 & & \\
\hline age (years), mean & 32.1 & 30.8 & $\ldots$ & 0.29 & & \\
\hline \multicolumn{7}{|l|}{ Professional category } \\
\hline physician & $10(18.5)$ & $28(39.4)$ & $0.35(0.15-0.81)$ & 0.01 & $0.40(0.16-0.97)$ & 0.04 \\
\hline nurse & $13(24.1)$ & $14(19.7)$ & $1.29(0.55-3.04)$ & 0.56 & & \\
\hline nursing technician/auxiliary & $26(48.1)$ & $22(31.0)$ & $2.07(0.99-4.31)$ & 0.051 & & \\
\hline other professions* & $5(9.3)$ & $7(9.9)$ & $0.93(0.28-3.12)$ & 0.91 & & \\
\hline \multicolumn{7}{|l|}{ Other professional data } \\
\hline years working in healthcare field, median (range) & $5(1-31)$ & $5(1-21)$ & $\ldots$ & 0.33 & & \\
\hline years working in the study hospital, median (range) & $3(1-5)$ & $2.5(1-5)$ & $\ldots$ & 0.048 & $1.32(1.00-1.74)$ & 0.049 \\
\hline simultaneous jobs in other hospitals & $26(49.1)$ & $33(47.8)$ & $1.05(0.51-2.14)$ & 0.88 & & \\
\hline weekly hours working in the hospital, median (range) & $40(20-64)$ & $36(20-64)$ & $\ldots$ & 0.07 & & \\
\hline working in the pediatrics unit & $13(24.1)$ & $3(4.2)$ & $7.19(1.93-26.74)$ & 0.001 & $7.35(1.90-28.44)$ & 0.004 \\
\hline working in the intensive care unit & $19(35.2)$ & $14(19.1)$ & $2.21(0.99-4.96)$ & 0.052 & & \\
\hline \multicolumn{7}{|l|}{ Reported number of patients cared for in a week } \\
\hline total, median (range) & $8(2-43)$ & $10(2-50)$ & $\ldots$ & 0.11 & & \\
\hline under isolation precautions, median (range) & $1(0-11)$ & $2(0-12)$ & $\ldots$ & 0.07 & & \\
\hline Knowledge of proper isolation precautions for patients with Influenza ${ }^{* *}$ & $16(29.6)$ & $16(22.5)$ & $1.45(0.65-3.24)$ & 0.37 & & \\
\hline \multicolumn{7}{|c|}{ Note. All data are in number (\%) unless otherwise specified. Statistically significant predictors are shown in bold. } \\
\hline N: number of subjects, OR: odds ratio, CI: confidence interval. & & & & & & \\
\hline
\end{tabular}


TABLE 2 - Predictors for adherence to three or more influenza vaccination campaigns in the last five years: univariate and multivariate analysis.

\begin{tabular}{|c|c|c|c|c|c|c|}
\hline \multirow[b]{3}{*}{ Predictors } & \multicolumn{4}{|c|}{ Univariate analysis } & & \\
\hline & \multirow{2}{*}{$\begin{array}{c}>3 \text { campaigns } \\
(\mathrm{n}=23)\end{array}$} & \multirow{2}{*}{$\begin{array}{c}<3 \text { campaigns } \\
(\mathrm{n}=44)\end{array}$} & \multirow[b]{2}{*}{ OR $(95 \% \mathrm{CI})$} & \multirow[b]{2}{*}{$\mathrm{P}$} & \multicolumn{2}{|c|}{ Multivariate analysis } \\
\hline & & & & & OR $(95 \% \mathrm{CI})$ & $\mathrm{P}$ \\
\hline \multicolumn{7}{|l|}{ Demographic data } \\
\hline male & $6(26.1)$ & $20(45.5)$ & $0.42(0.14-1.28)$ & 0.12 & & \\
\hline age (years), mean & 33.6 & 32.8 & $\ldots$ & 0.59 & & \\
\hline \multicolumn{7}{|l|}{ Professional category } \\
\hline physician & $4(17.4)$ & $24(54.5)$ & $0.18(0.05-0.60)$ & 0.003 & $0.17(0.05-0.60)$ & 0.006 \\
\hline nurse & $3(13.0)$ & $4(9.1)$ & $1.50(0.31-7.36)$ & 0.68 & & \\
\hline nursing technician/auxiliary & $12(52.2)$ & $11(25.0)$ & $3.27(1.13-9.50)$ & 0.03 & & \\
\hline other professions* & $4(17.4)$ & $5(11.4)$ & $1.64(0.40-6.83)$ & 0.48 & & \\
\hline \multicolumn{7}{|l|}{ Other professional data } \\
\hline years working in healthcare field, median (range) & $9(5-31)$ & $7(2-27)$ & $\ldots$ & 0.31 & & \\
\hline years working in the study hospital, median (range) & $3(1-5)$ & $3(1-5)$ & $\ldots$ & 0.97 & & \\
\hline simultaneous job in other hospital & $11(47.8)$ & $27(64.3)$ & $0.51(0.18-1.43)$ & 0.2 & & \\
\hline weekly hours working in the hospital, median (range) & $36(30-40)$ & $36(20-40)$ & $\ldots$ & 0.88 & & \\
\hline working in the pediatrics unit & $3(13.0)$ & $6(13.6)$ & $0.95(0.22-4.21)$ & 1 & & \\
\hline working in the intensive care unit & $9(39.1)$ & $8(18.2)$ & $2.89(0.93-9.00)$ & 0.06 & & \\
\hline \multicolumn{7}{|l|}{ Reported number of patients cared for in a week } \\
\hline total, median (range) & $7.5(2-30)$ & $10(2-50)$ & $\ldots$ & 0.07 & & \\
\hline under isolation precautions, median (range) & $2(0-10)$ & $2(0-12)$ & $\ldots$ & 0.68 & & \\
\hline Knowledge of proper isolation precautions for patients with Influenza ${ }^{* *}$ & $9(39.1)$ & $12(27.3)$ & $1.71(0.59-4.99)$ & 0.32 & & \\
\hline \multicolumn{7}{|c|}{ Note. All data are in number (\%) unless otherwise specified. Statistically significant predictors are outlined in bold. } \\
\hline \multicolumn{7}{|l|}{$\mathrm{N}$ : Number of subjects; OR: odds ratio, CI: confidence interval. } \\
\hline
\end{tabular}

showed that HCWs working in pediatric units and those working in the hospital for a longer period were more likely to have been vaccinated against influenza. However, physicians displayed lower adherence to vaccination.

\section{Adherence to three or more influenza vaccination campaigns in the last five years}

A total of $67 \mathrm{HCWs}$ were eligible for this analysis. Twenty-three (34.3\%) had been vaccinated three or more times in the last five years. Table 2 presents results from univariate and multivariate analyses. The medical profession was once again associated with poorer adherence according to the latter.

\section{DISCUSSION}

The nonmaleficence axiom, primum non nocere, is perhaps the soundest argument for HCW immunization. However, claims regarding the moral obligation of not infecting patients are clearly insufficient to ensure adherence to influenza vaccination campaigns ${ }^{9,10}$. Hospitals must therefore develop their own strategies of improving vaccine coverage among staff. This is why studies concerning vaccination adherence predictors are of the utmost importance.

A recent paper by Hollmeyer et $\mathrm{al}^{11}$ reviewed literature on knowledge and adherence predictors for influenza vaccination in HCWs working in hospitals. Twenty-one published articles were included in the review. The most commonly cited reason for non-receipt of influenza vaccine was fear of adverse reaction, closely followed by lack of concern. However, the most common reason for adhering to influenza vaccination campaigns was self-protection with protection of patients ranking a poor second. The authors concluded that when HCWs are immunized against influenza, they do so for their own benefit and not as a concern for patient safety. This poses a major challenge for infection control.

Shortly after this review came out, Loulergue et $\mathrm{al}^{12}$ published a paper focusing on the knowledge and attitudes of HCWs to occupational vaccinations. The authors reported that only $52 \%$ of HCWs from a teaching hospital in Paris (France) were aware of the occupational indication for influenza vaccination. They verified greater awareness among physicians and pediatric staff. Knowledge regarding vaccine recommendations was an independent predictor of vaccination adherence. These results have both similarities and contrasts with those obtained in this work.

In the present study, HCWs working in pediatric units were more likely to have been vaccinated. This is rather puzzling, since annual Brazilian influenza campaigns stress the risks of influenza for the elderly ${ }^{13}$. It is worth noting that all but the pediatric units in our hospital predominantly admit patients aged 60 years-old or over. Greater influenza vaccine uptake for HCWs caring for these elderly patients would be expected; however, the results were exactly the opposite and could imply serious misconceptions regarding the importance of immunization.

Several studies have reported physicians as a group with greater adherence to influenza vaccination ${ }^{12,14,15}$. The explanation for these findings would be greater knowledge concerning the efficacy and safety of the vaccine ${ }^{12}$. However, in this study, physicians were both less likely to have been vaccinated in 2007 and to have adhered to three or more campaigns in the last five years. From our perspective, 
this is not a matter of lack of knowledge; rather, that it reflects the poor likelihood of physicians to adhere to infection control guidelines. This does not apply only to immunization issues. A recent review reports that physicians had the worst performance in several studies of compliance to hand hygiene procedures ${ }^{16}$.

The number of years since admission to our hospital was positively associated with adherence to the 2007 vaccination campaign. This may imply the occurrence of a virtuous cycle: the longer the HCWs work in our hospital, the greater the likelihood of receiving a vaccine. Other authors have described this virtuous cycle based on a different finding. In their results, receiving influenza vaccination in one year strongly predicted adherence to the following year's campaign ${ }^{12,14}$.

Other findings from this study must also be highlighted. Receiving influenza vaccine was not influenced by knowledge of the proper isolation precautions for patients with influenza-like illnesses. Moreover, frequent care for patients under isolation precautions did not predict vaccination. These findings suggest that adherence has little to do with knowledge or experience. It probably has more to do with behavioral patterns and future research should focus on this issue using both quantitative and qualitative approaches.

Taken together, the results of our group suggest that policies to assure good influenza vaccine coverage in our hospital should focus on physicians and newly-admitted HCWs. These policies should be designed to assess not just knowledge, but also the attitudes, beliefs and lifestyle of different professional categories. Furthermore, previous experience demonstrates that interventions must be continuous; otherwise, adherence may rapidly fall rapidly over time ${ }^{17}$.

Finally, following the emergence of the 2009 A H1N1 influenza pandemic, the question of whether the present findings are still valid should be asked. It is true that memory of recent events prompted greater adherence by HCWs for vaccination against the pandemic strain. However, attitudes concerning pandemic Influenza still vary widely among professional categories ${ }^{18}$. In the future, now the pandemic has ended, it is possible that HCWs will behave as they did in the prepandemic era. Therefore, knowledge regarding vaccination predictors will still contribute toward the challenge of assuring good coverage for vaccination campaigns and, ultimately, in preventing the transmission of the influenza virus within hospitals.

\section{CONFLICT OF INTEREST}

The authors declare that there are no conflicts of interest.

\section{REFERENCES}

1. Ferguson JK, Stuart RL, Cheng AC, Marshall CL. Healthcare infection control special interest group of the Australian Society for Infectious Diseases. ASID (HICSIG) position statement: infection control guidelines for patients with Influenza-like illnesses, including pandemic (H1N1) Influenza 2009, in Australian health care facilities. Med J Aust 2009; 191:454-458.

2. Salgado CD, Barr BM, Hall KK, Hayden FG. Influenza in the acute hospital setting. Lancet Infect Dis 2002; 2:145-155.

3. Maltezou HC. Nosocomial Influenza: new concepts and practice. Curr Opin Infect Dis 2008; 21:337-343.

4. Talbot TR, Bradley SE, Cosgrove SE, Ruef C, Siegel JD, Weber DJ. Influenza vaccination of healthcare workers and vaccine allocation for healthcare workers during vaccine shortages. Infect Control Hosp Epidemiol 2005; 26:882-890.

5. Elder AG, O’Donnel B, McCruden EA, Symington IS, Carman WF. Incidence and recall of Influenza in a cohort of Glasgow healthcare workers during the
1993-4 epidemic: results of serum testing and questionnaire. BMJ 1996; 313 : 1241-1242.

6. Heimberger T, Chang HG, Shaikh M, Crotty L, Morse D, Birkhead G. Knowledge and attitudes of healthcare workers about Influenza: why are they not getting vaccinated? Infect Control Hosp Epidemiol 1995; 16:412-415.

7. Garner JS. Guideline for isolation precautions in hospitals. The Hospita Infection Control Practices Advisory Committee. Infect Control Hosp Epidemiol 1996; 17:53-80.

8. Greenland S. Modeling and variable selection in epidemiologic analysis. Am J Public Health 1989; 79:340-349.

9. Harris J, Holm S. Is there a moral obligation not to infect others? BMJ 1995; 311:1215-1217.

10. Lugo NR. Will carrots or sticks raise Influenza immunization rates of health care personnel? Am J Infect Control 2007; 35:1-6.

11. Hollmeyer HG, Hayden F, Poland G, Buchholz U. Influenza vaccination of healthcare workers in hospitals - a review of studies on attitudes and predictors. Vaccine 2009; 27:3935-3944.

12. Loulergue P, Moulin F, Vidal-Trecan G, Demontipion C, Menager C, Gorodetsky $\mathrm{M}$, et al. Knowledgem attitudes and vaccination coverage of healthcare workers regarding occupational vaccinations. Vaccine 2009; 27:4240-4243.

13. Donalisio MR. Brazilian policy for Influenza vaccination and its impact on the health of the elderly. Cad Saude Publica 2007; 23:494-495.

14. Beguin C, Boland B, Ninane J. Healthcare workers: vectors of Influenza virus? Low vaccination rate among hospital health care workers. Am J Med Qual 1998; 13:223-227.

15. Doebbeling BN, Edmond MB, Davis CS, Woodin JR, Zeitler RR. Influenza vaccination of healthcare workers: evaluation of factors that are important in acceptance. Prev Med 1997; 26:68-77.

16. Pittet D. Improving adherence to hand hygiene practice: a multidisciplinary approach. Emerg Infect Dis 2001; 7:234-240.

17. Takayanagi IJ, Cardoso MRA, Costa SF, Araya ME, Machado CM. Attitudes of health care workers to Influenza vaccination: Why are they not vaccinated? Am J Infect Control 2007; 35:56-61.

18. La Torre G, Di Thiene D, Cadeddu C, Ricciardi W, Boccia A. Behaviours regarding preventive measures against pandemic $\mathrm{H} 1 \mathrm{~N} 1$ Influenza among Italian healthcare workers, October 2009. Euro Surveill 2009;14:pii-19432. 